\title{
脳波からみた介護老人福祉施設入居者における仰臥位から坐位への 姿勢变化がもたらす脳活動
}

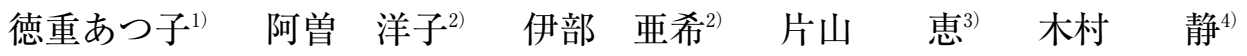

\begin{abstract}
要 約 目的：仰臥位から坐位へ姿勢を変化させた時の大脳の活動状態を脳波のパワースペクトルを用いて 分析し, 姿勢変化がもたらす脳活動について検証を行うことを目的とした．方法：対象者は介護老人福祉施 設入居者 17 人（男性 4 人, 女性 13 人, 平均年齢 $85.35 \pm 8.26$ 歳) である. 本研究は大阪大学の保健学倫理 委員会の承認を受けて行った。 デー夕収集は, 頭側挙上を行ったベッド上での坐位と椅子又は車椅子を利用 した坐位の 2 種類の設定で行った。ベッド上坐位の頭部挙上角度は，坐位に近い 70 度とした，椅子坐位は， 対象者が普段とっている姿勢（椅子利用 9 人，車椅子利用 8 人）とした。椅子では足底を床に，車椅子では 足をフットレストに乗せ, 背もたれにもたれた姿勢とした. 測定項目は, 脳波 (8 点, $\mathrm{Fp}_{1}$ ：左前頭極部, $\mathrm{Fp}_{2}$ ： 右前頭極部, $\mathrm{F}_{3}$ : 左前頭部, $\mathrm{F}_{4}$ : 右前頭部, $\mathrm{C}_{3}$ : 左中心部, $\mathrm{C}_{4}$ : 右中心部, $\mathrm{O}_{1}$ : 左後頭部, $\mathrm{O}_{2}$ : 右後頭部) である. 測定時間は, 仰臥位 5 分, 坐位 15 分, 会話 5 分である. 会話内容は, 坐位の感想や現在の気分等 である. 分析区間は 5 分毎とし, ベッド挙上時と椅子への移乗時のデー夕は除外して分析した．脳波はFFT 後， $\alpha$ 帯域成分 $(8 \sim 13 \mathrm{~Hz})$ と $\beta$ 带域成分 $(13 \sim 30 \mathrm{~Hz})$ のパワー值の平均值を区間毎に算出した. 結果 : ベッド上坐位では, 仰臥位時と比較して姿勢変化による有意なパワー值の増加はみられなかった. 椅子坐位 では，全ての測定部位で有意なパワー值の増加を認めた．また，全部位で椅子坐位の方がベッド上坐位より パワー值が有意に大きい時間帯が多かった，特に会話においては, $\mathrm{Fp}_{2}$ 以外は全て椅子坐位の方がベッド上 坐位よりもパワー值が有意に大きかった，結論：仰臥位から坐位への姿勢変化がもたらす大脳活性は, 姿勢 変化後 20 分間に関してはベッド上坐位よりも椅子坐位の方が大きいことが示された.
\end{abstract}

Key words : 脳波, 坐位, 老人福祉施設, 高齢者, 脳活性

（日老医誌 $2011 ； 48 ： 378-390)$

\section{緒 言}

坐位姿勢は, 生活の基本となる衣食住を充足させるた めにはなくてはならない姿勢である. 特に, ベッド上で の生活を余儀なくされている人にとっては,坐位姿勢は, 食事, 洗面, 排泄の自立を左右する ${ }^{1}$ 姿勢である. 先行 研究に扔いては，低 ADL が死亡リスクを高めるという ことも示されている2) 5). また, 高齢者においては, 坐 位を保持することによって QOL が向上したとの報告も ある ${ }^{677}$.

仰臥位から坐位へ姿勢を変化させると, 視覚, 聴覚, 体性感覚, 内臓感覚等, 様々な感覚情報が入ってくる.

1) A. Tokushige : 明治国際医療大学看護学部

2) Y. Aso, A. Ibe : 大阪大学大学院医学系研究科保健学 専攻

3) M. Katayama : 神戸大学大学院保健学研究科

4) S. Kimura：宝塚大学看護学部

受付日：2009.1.19, 採用日：2011.4.12
これらの情報は脳幹網様体で統合され，視床を介して大 脳皮質に送られ，大脳の活性化が起こると考えられる (Moruzzi と Magounの上行性網様体賦活系の機能概 念 ${ }^{8}$ による)，坐位姿勢の援助によって，表情の変化や発 語の増加 ${ }^{9}$, 意識レベルの改善 ${ }^{10)}$ がみられたとの報告も あり，坐位保持具も開発されてきている ${ }^{11122}$.

また, 網様体賦活系の一部を形成している縫線核（5HT）は，交感神経を興奮させて血圧や心拍数を上昇さ せる等の自律神経の調整にも関与していることがわかっ ており ${ }^{13}$, 坐位姿勢時には交感神経活動が活性化すると の報告もある ${ }^{14) \sim 16)}$. さらに, 縫線核 (5-HT) はうつと の関連も明らかとなっている ${ }^{17)}$. うつ状態では, 精神運 動制止が起こるため, 人は意欲的になることができない. 高齢者においては, 自立意欲は生命予後と関連がある ${ }^{18}$ との報告もある.

以上のことから, 坐位姿勢の援助は, 大脳を刺激し, 交感神経活動を促す等生体を活性化する効果があり, QOL 向上や自立意欲の促し等への活用も可能であると 
考えられる.

しかしながら, 坐位姿勢による大脳の活性化を直接検 証した研究はこれまでになかった，筆者らは健康成人を 対象に，脳波を用いてベッド上に打ける仰臥位から坐位 への姿勢変化に伴う大脳の活性化を確認した ${ }^{19)}$. また, 対象者を健康な高齢者として同様の研究を行ったとこ ろ, 大脳の活性化は確認されたが統計上有意な活性は一 部であった ${ }^{20)}$.

そこで, 本研究では, 対象を介護老人福祉施設の入居 者とし，仰臥位から坐位へ姿勢を変化させることが大脳 を活性化させるかどうかを，ベッド上坐位と椅子坐位の 二つのパターンについて，脳波計測に基づいた検証を 行ったので報告する.この研究を本稿においては研究 1 とする. また, この結果を健康者と比較しての検討も行っ た.この比較を研究 2 とする.

\section{研究 1 (介護福祉施設入居者についての検討)}

I. 方法

1. 対象者

京都市内にある 60 床の介護老人福祉施設の入居者で, 研究の趣旨に同意が得られた 18 人（男性 4 人，女性 14 人）に対して研究を行った.

2. デー夕収集期間

研究者が施設を訪問し, 平成 20 年 2 月 21 日から 3 月 28 日の間の 30 日間データ収集を行った.

3. デー夕収集項目

（1）基礎デー夕

年齢, 障害高齢者の日常生活自立度, 認知症高齢者の 日常生活自立度, 要介護度, 車椅子使用の有無, 基礎疾 患, 服薬状況, 麻瘏の状況, 利き手.

(2) 脳波デー夕

仰臥位時, 坐位姿勢時, 会話時の脳波データを収集し た.

4. 脳波の測定带域, 測定部位, 測定機器

本研究では，FFTを用いたスペクトル分析を行った. $\alpha$ と $\beta$ 帯域における脳波パワー值について検討を行うこ ととし, 带域の設定は $\alpha$ 帯域 ( $8.0 \mathrm{~Hz}$ 以上 $13.0 \mathrm{~Hz}$ 以下), $\beta$ 帯域 (13.0 Hz を含まずそれ以上 $30.0 \mathrm{~Hz}$ 未満) とした. 測定部位は，国際 10/20 法に基づき， 8 点（ $\mathrm{Fp}_{1}$; 左前 頭極部, $\mathrm{Fp}_{2}$; 右前頭極部, $\mathrm{F}_{3}$; 左前頭部, $\mathrm{F}_{4}$; 右前頭 部, $\mathrm{C}_{3}$; 左中心部, $\mathrm{C}_{4}$; 右中心部, $\mathrm{O}_{1}$; 左後頭部, $\mathrm{O}_{2}$; 左後頭部）とした，脳波のスペクトル分析では，目的と する带域の脳波を定量的に表現することができるため， 分析手法として用いることとした，带域の選択理由は， それぞれの帯域に対応する脳波リズムの性質による， $\alpha$
波はリラックスした覚醒時の代表波形であることと， $\beta$ 波は活発な皮質が発する代表波形であることによる ${ }^{21222}$. 導出方法は左耳架をマイナス電極とした基準導出（単極 誘導) 法とし, 右耳架をアースとした. 測定には EEG100C 脳波計（BIOPAC Systems 社製）を用い，電極はキャッ プ式の ECI Electro-Cap Electrode System（ELECTROCAP INTERNATIONAL) を使用した. データの取り 込みは, A/D 変換器として MP100System (BIOPAC Sys-

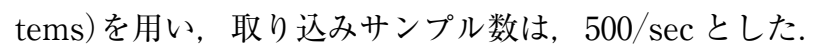
データ取り达みと分析に使用したソフトは Acqknowledge（BIOPAC Systems, Ver.3.81) である. フィル夕 は，脳波アンプによる $0.1 〜 35 \mathrm{~Hz}$ のバンドパスを用い た.

5. 本研究における前提条件と脳活性の定義

本研究では, 覚醒時における仰卧位から坐位への姿勢 変化に伴う大脳活動のデー夕を得たいと考えたため, 対 象者の開眼, 覚醒を前提条件とした. デー夕収集中の覚 醒状態の確認は, 対象者の様子観察によって行うことと した.

本研究においては, 大脳皮質一視床ニューロンの活性 化の結果として現れる $\beta$ 帯域の脳波パワー值の増加 ${ }^{211}$ を 脳活性と定義する． $\alpha$ 帯域の脳波パワー值は覚醒の程度 の判断 ${ }^{22} 233$ に用いることとし, パワー值の減少により覚 醒度が低下したと判断することとする。また, 緊張や興 奮状態においても脳波のパワー值には変化が生じると考 えられるため, 対象者に過度の心身負荷がかかっていな いかどうか, 覚醒状態と共にデー夕収集中に目視による 確認を行い, 該当者がいる場合は, 状態に合わせてデー 夕収集の中断の判断を行うこととした。

6. 測定環境とデータ収集手順

デー夕収集は各対象者の居室で行った. 環境の妥当性 を判断するために温度, 湿度, 照度, 騒音レベル（A 特性周波数重み付け音圧レベル）の測定を行った.

研究デザインにはクロスオーバーデザインを用いて, 全ての対象者にベッド上と椅子の二つの坐位姿勢につい てデー夕収集を行った（以下，ベッド上での坐位姿勢を ベッド上坐位, 椅子での坐位姿勢を椅子坐位とする). デー夕収集は 1 人につき 1 日 1 回とし, 順序効果を除外 する為にカウンタバランスをとって, 経験する坐位姿勢 の順序を対象者每にランダムに決定した。ベッドは各居 室同一規格の, 背と膝を挙げることが可能な汎用型の電 動ベッドを用いた．椅子は対象者が居室で使用している ものを用いた，手順の詳細を以下に示す.

（1）機器を装着して 10 分間安静臥床後に測定を開始 した，測定姿勢は，開眼，安静とし，体動も最小限とし 


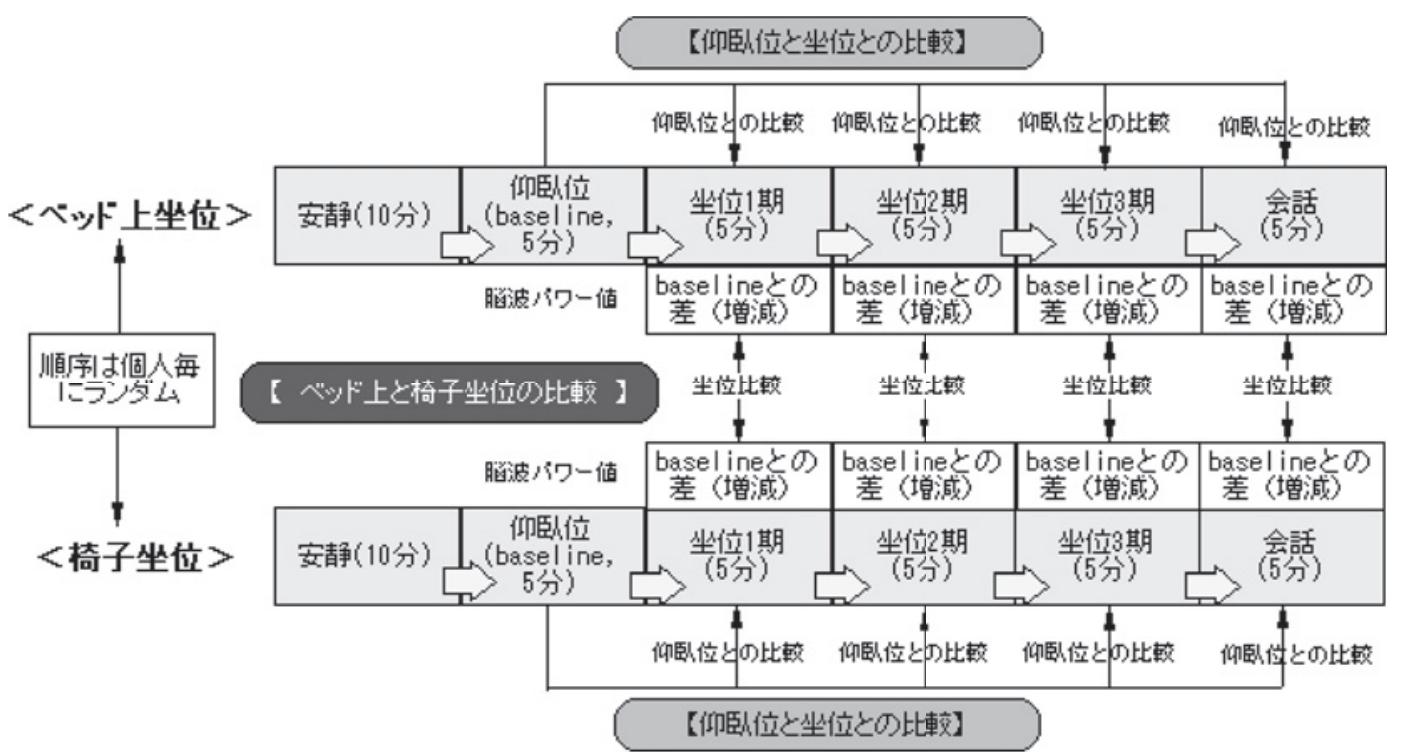

図1 研究の流れとデータの比較方法

た.

（2）ベッド上坐位は，仰臥位をとった後，ベッドの挙 上にて坐位姿勢をとった，椅子坐位は，同じくべッド上 で仰臥位をとった後, 椅子に移動してもらった。

（3）ベッド上坐位は, 力を抜いてベッドの背にもたれ たままの受動姿勢とした。ベッドの挙上角度は椅子坐位 の角度に近い 70 度に設定した．同時に上体のずり落ち 防止のため, ベッドの膝上げ機能を用いて，膝を対象者 の好みの高さまで挙上した。椅子坐位は, 足底を接地し て椅子の背にもたれてもらった。

（4）測定する姿勢及び時間は，仰臥位 5 分，坐位 15 分, 会話 5 分である. ベッドの操作や移動介助等の時間 は約 3 分間とした，会話は，筆者と坐位姿勢のまま 5 分 間行った，主な内容は，坐位姿勢の感想や現在の気分等 である。

7. 分析方法

（1）脳波データの分析区間の設定

分析を行う区間の設定を，仰臥位，坐位 1 期，坐位 2 期，坐位 3 期，会話時の各 5 分毎とした．坐位姿勢の 15 分間を三つの区間に分けたのは，坐位姿勢後の時間的な 経過による変化をみるためである. ベッドの挙上・調節 を行う 3 分間は坐位 1 期に含むが，分析そのものからは 除外した。

（2）脳波の信号処理とパワー值の出し方

脳波パワー值（単位 $; \mu \mathrm{V}^{2}$ ) を上記デー夕区間毎に算 出した，ノイズの確認は，脳波の波形画面上並びに脳波 信号のスペクトログラム上に扔いて, 目視により行った. データ区間毎に瞬目や眼球運動, 体動時の筋電等のノイ
ズの少ない安定した時間帯を選択して FFT（Fast Fourier Transform ; 高速フーリエ変換)を行った. FFT に用いた密関数はハニング空である．FFTで得られた フーリエスペクトルを 2 乗してパワースペクトルを算出 した.

（3）収集データの比較方法（図 1）

比較に用いたパワー值は, 各データ区間の安定した時 間帯から選択した 20 秒ずつ 3 カ所（各区間それぞれ合 計 1 分）のパワー值の平均值である. 以下に述べる方法 で, $\alpha$ 及び $\beta$ 帯域パワー值の比較を行った.

1）仰臥位とベッド上並びに椅子坐位の比較：

それぞれの坐位姿勢の設定における仰卧位時の值を baseline として, 各々の baseline と坐位各区間のパワー 值を比較した.

2) ベッド上坐位と椅子坐位の比較

仰臥位時の值を baseline として, baseline と各坐位各 区間のパワー值の差を算出した。この baseline との差 の值を用いて, 各坐位区間について姿勢間の比較を行っ た。

\section{8. 統計的分析について}

有意水準は $5 \%$ とし, 統計ソフトには SPSS12.0J を使 用した。得られた脳波デー夕は個人差が大きく, SPSS による正規性の検定（Kolmogorov-Smirnov 検定）によ り正規分布していないものが確認されたため, 統計学的 な検定にはノンパラメトリックな手法を用いることとし た．分析では，仰臥位と各坐位区間との比較は Bonferroni の不等式で有意水準を補正した Wilcoxon の符号付 順位和検定を用いて多重比較を行った（有意水準= 
表 1 対象者の基本属性

\begin{tabular}{|c|c|c|c|c|}
\hline 項目 & 区分 & 人数 & 年齢（SD） & 全体年齢 \\
\hline 性別 & $\begin{array}{l}\text { 男性 } \\
\text { 女性 }\end{array}$ & $\begin{array}{r}4 \\
13\end{array}$ & $\begin{array}{l}85.25(5.91) \\
85.38(9.10)\end{array}$ & $85.35(8.26)$ \\
\hline 障害高齢者の日常生活自立度 & $\begin{array}{l}\mathrm{J} \\
\mathrm{A} \\
\mathrm{B} \\
\mathrm{C}\end{array}$ & $\begin{array}{l}1 \\
9 \\
6 \\
1\end{array}$ & $\begin{array}{l}86.00 \\
83.89(10.15) \\
85.83(5.53) \\
95.00\end{array}$ & \\
\hline 認知症高齢者の日常生活自立度 & $\begin{array}{l}\text { I } \\
\text { II } \\
\text { III } \\
\text { IV } \\
\text { M }\end{array}$ & $\begin{array}{l}0 \\
6 \\
5 \\
6 \\
0\end{array}$ & $\begin{array}{ll} & - \\
85.00 & (5.90) \\
88.20 & (3.63) \\
83.33 & (12.64) \\
& -\end{array}$ & \\
\hline 要介護度 & $\begin{array}{l}1 \\
2 \\
3 \\
4 \\
5\end{array}$ & $\begin{array}{l}0 \\
1 \\
7 \\
7 \\
2\end{array}$ & \begin{tabular}{ll}
\multicolumn{1}{c}{} & - \\
80.00 & \\
86.86 & $(5.52)$ \\
82.14 & $(10.33)$ \\
94.00 & $(1.41)$
\end{tabular} & \\
\hline 車椅子使用 & $\begin{array}{l}\text { 有 } \\
\text { 無 }\end{array}$ & $\begin{array}{l}8 \\
9\end{array}$ & $\begin{array}{l}87.88(6.03) \\
83.11\end{array}$ & \\
\hline
\end{tabular}

表 2 対象者の主な疾患, 麻痺の状況, 利き手

\begin{tabular}{|c|c|c|c|c|}
\hline 項目 & 区分 & 人数 & 服薬 & 人数 \\
\hline 疾患名 & $\begin{array}{l}\text { 脳梗塞 } \\
\text { 糖尿病 } \\
\text { 高血圧症 } \\
\text { 認知症 }\end{array}$ & $\begin{array}{l}4 \\
4 \\
2 \\
7\end{array}$ & $\begin{array}{l}\text { 有 } \\
\text { 無 } \\
\text { 有 } \\
\text { 無 } \\
\text { 有 } \\
\text { 無 } \\
\text { 有 } \\
\text { 無 }\end{array}$ & $\begin{array}{l}0 \\
4 \\
4 \\
0 \\
2 \\
0 \\
2 \\
5\end{array}$ \\
\hline 麻痺 & $\begin{array}{l}\text { 四肢麻疩 } \\
\text { 片麻痺 } \\
\text { 単麻痺 } \\
\text { 対麻痺 }\end{array}$ & $\begin{array}{l}0 \\
2 \\
0 \\
0\end{array}$ & & \\
\hline 利き手 & $\begin{array}{l}\text { 右 } \\
\text { 左 }\end{array}$ & $\begin{array}{r}16 \\
1\end{array}$ & * 利 & 奥にて \\
\hline
\end{tabular}

$\mathrm{n}=17$

$0.012 \doteqdot 0.05 / 4)$. ベッド上坐位と椅子坐位との比較にお いては，Wilcoxonの符号付順位和検定を用い，比較に は baseline との差の值を用いた。

\section{9. 倫理的配慮}

本研究は, 大阪大学保健学倫理委員会の承認を得て 行った。対象者には研究の趣旨, 匿名性の確保, 研究へ の参加，途中辞退の自由について文書と口頭により説明 して同意を得た。認知症等で本人の同意を得ることが困 難な対象者には，身元引受者の同意をとった.
II. 結果

1. 対象者

データ欠損があった 1 人を除き 17 人の対象者のデー 夕について分析を行った. 17 人の内訳は男性が 4 人, 女性が 13 人で, 平均年齢は $85.35 \pm 8.26$ 歳であった.

2. 基礎デー夕（表 $1 ， 2$ ）

対象者の基礎データは表 $1 ， 2$ に示した。基礎疾患は, 脳梗塞, 糖尿病, 高血圧症, 認知症であったが, 脳波に 影響を及ぼすような服薬はなかった。なお，認知症高齢 者の日常生活自立度においては，II 6 人， III 5 人， IV 6 人であった。認知機能の状況については，常に対象者の ケアを行っている介護職員からの情報を参考に, 研究者 自らも, 対象者全員に認知機能に何らかの問題があるこ とを確認した。アルツハイマー型認知症治療薬（塩酸ド ネペジル）服用者は 2 人いたが，長期に服用しているも のであるため, 今回の研究デー夕には影響がないと考え て分析に加えた。

3. 研究の前提条件

デー夕収集中目視で観察を行ったが，眠っている者は いなかった. また, 大きな体動や苦痛の訴えもなかった.

\section{4. 測定環境}

データ収集期間中の環境に関する測定值の平均と標準 偏差は以下の通りである。温度は $22.6 \pm 2.3^{\circ} \mathrm{C}$, 湿度は $33.5 \pm 6.9 \%$, 照度は $253.9 \pm 86.2$ lux, 最大騒音レベルは $58.9 \pm 8.3 \mathrm{~dB}$ ，最小騒音レベルは $40.0 \pm 2.2 \mathrm{~dB}$ であった. 
表 3 坐位姿勢毎の $\alpha$ 帯域脳波パワー值と多重比較の結果

\begin{tabular}{|c|c|c|c|c|c|c|c|c|}
\hline & \multicolumn{2}{|c|}{ ベッド上坐位 } & \multicolumn{2}{|c|}{ 椅子坐位 } & \multicolumn{2}{|c|}{ ベッド上坐位 } & \multicolumn{2}{|c|}{ 椅子坐位 } \\
\hline & パワー值 & $\begin{array}{l}\text { Wilcoxon } \\
\text { 検定 }\end{array}$ & パワー值 & $\begin{array}{l}\text { Wilcoxon } \\
\text { 検定 }\end{array}$ & パワー值 & $\begin{array}{l}\text { Wilcoxon } \\
\text { 検定 }\end{array}$ & パワー值 & $\begin{array}{l}\text { Wilcoxon } \\
\text { 検定 }\end{array}$ \\
\hline $\begin{array}{l}\text { 仰臥位 } \\
\text { 坐位 } 1 \text { 期 } \\
\text { 坐位 } 2 \text { 期 } \\
\text { 坐位 } 3 \text { 期 } \\
\text { 会話 }\end{array}$ & $\begin{array}{l}\mathrm{Fp}_{1} \\
3.3 \pm 1.5 \\
4.1 \pm 1.7 \\
3.7 \pm 1.6 \\
3.8 \pm 1.5 \\
5.1 \pm 1.8\end{array}$ & $\begin{array}{c}- \\
0.020 \\
0.924 \\
0.619 \\
0.023\end{array}$ & $\begin{array}{l}3.1 \pm 1.3 \\
5.1 \pm 1.3 \\
4.3 \pm 1.3 \\
4.6 \pm 1.5 \\
5.6 \pm 1.3\end{array}$ & $\begin{array}{c}- \\
0.004 \\
0.018 \\
0.068 \\
0.006\end{array}$ & $\begin{array}{l}\mathrm{Fp}_{2} \\
2.3 \pm 1.1 \\
3.0 \pm 1.4 \\
2.9 \pm 1.4 \\
3.1 \pm 1.4 \\
3.7 \pm 1.4\end{array}$ & $\begin{array}{c}- \\
0.134 \\
0.795 \\
0.959 \\
0.031\end{array}$ & $\begin{array}{l}2.3 \pm 1.1 \\
4.9 \pm 1.3 \\
4.2 \pm 1.3 \\
4.6 \pm 1.5 \\
5.2 \pm 1.4\end{array}$ & $\begin{array}{c}- \\
0.004 \\
0.006 \\
0.002 \\
0.000\end{array}$ \\
\hline $\begin{array}{l}\text { 仰臥位 } \\
\text { 坐位 } 1 \text { 期 } \\
\text { 坐位 } 2 \text { 期 } \\
\text { 坐位 } 3 \text { 期 } \\
\text { 会話 }\end{array}$ & $\begin{array}{l}\mathrm{F}_{3} \\
3.4 \pm 1.5 \\
4.1 \pm 1.7 \\
3.9 \pm 1.8 \\
4.0 \pm 1.8 \\
5.0 \pm 2.2\end{array}$ & $\begin{array}{c}- \\
0.079 \\
0.435 \\
0.605 \\
0.177\end{array}$ & $\begin{array}{l}2.0 \pm 0.7 \\
5.7 \pm 1.5 \\
4.5 \pm 1.3 \\
4.6 \pm 1.3 \\
6.0 \pm 1.4\end{array}$ & $\begin{array}{c}- \\
0.002 \\
0.007 \\
0.010 \\
0.000\end{array}$ & $\begin{array}{l}\mathrm{F}_{4} \\
2.9 \pm 1.3 \\
3.6 \pm 1.7 \\
3.4 \pm 1.6 \\
3.4 \pm 1.6 \\
4.2 \pm 1.8\end{array}$ & $\begin{array}{c}- \\
0.368 \\
0.538 \\
0.831 \\
0.287\end{array}$ & $\begin{array}{l}2.5 \pm 1.3 \\
5.3 \pm 1.6 \\
4.2 \pm 1.4 \\
4.5 \pm 1.3 \\
5.6 \pm 1.5\end{array}$ & $\begin{array}{c}- \\
0.002 \\
0.011 \\
0.005 \\
0.000\end{array}$ \\
\hline $\begin{array}{l}\text { 仰臥位 } \\
\text { 坐位 } 1 \text { 期 } \\
\text { 坐位 } 2 \text { 期 } \\
\text { 坐位 } 3 \text { 期 } \\
\text { 会話 }\end{array}$ & $\begin{array}{l}\mathrm{C}_{3} \\
3.0 \pm 1.3 \\
3.7 \pm 1.6 \\
3.2 \pm 1.3 \\
3.4 \pm 1.4 \\
4.6 \pm 1.8\end{array}$ & $\begin{array}{c}- \\
0.185 \\
0.887 \\
0.586 \\
0.177\end{array}$ & $\begin{array}{l}2.4 \pm 1.2 \\
5.6 \pm 1.4 \\
4.4 \pm 1.2 \\
4.4 \pm 1.2 \\
6.0 \pm 1.4\end{array}$ & $\begin{array}{c}- \\
0.002 \\
0.019 \\
0.005 \\
0.000\end{array}$ & $\begin{array}{l}\mathrm{C}_{4} \\
3.6 \pm 1.3 \\
3.8 \pm 1.5 \\
3.5 \pm 1.4 \\
3.7 \pm 1.5 \\
7.7 \pm 3.2\end{array}$ & $\begin{array}{c}- \\
0.523 \\
0.813 \\
0.356 \\
0.287\end{array}$ & $\begin{array}{l}3.1 \pm 1.4 \\
6.6 \pm 1.9 \\
5.0 \pm 1.6 \\
4.9 \pm 1.5 \\
6.1 \pm 1.6\end{array}$ & $\begin{array}{c}- \\
0.000 \\
0.006 \\
0.002 \\
0.001\end{array}$ \\
\hline $\begin{array}{l}\text { 仰臥位 } \\
\text { 坐位 } 1 \text { 期 } \\
\text { 坐位 } 2 \text { 期 } \\
\text { 坐位 } 3 \text { 期 } \\
\text { 会話 }\end{array}$ & $\begin{array}{l}\mathrm{O}_{1} \\
1.4 \pm 0.3 \\
2.4 \pm 0.6 \\
2.0 \pm 0.6 \\
2.4 \pm 0.8 \\
3.3 \pm 0.8\end{array}$ & $\begin{array}{c}- \\
0.088 \\
0.085 \\
0.722 \\
0.035\end{array}$ & $\begin{array}{l}1.8 \pm 0.6 \\
6.0 \pm 1.4 \\
4.5 \pm 1.1 \\
4.5 \pm 1.1 \\
5.9 \pm 1.2\end{array}$ & $\begin{array}{c}- \\
0.001 \\
0.001 \\
0.005 \\
0.001\end{array}$ & $\begin{array}{l}\mathrm{O}_{2} \\
1.5 \pm 0.4 \\
2.3 \pm 0.6 \\
1.8 \pm 0.5 \\
2.3 \pm 0.7 \\
3.5 \pm 0.9\end{array}$ & $\begin{array}{c}- \\
0.381 \\
0.918 \\
0.962 \\
0.011\end{array}$ & $\begin{array}{l}1.8 \pm 0.7 \\
5.8 \pm 1.4 \\
4.1 \pm 1.2 \\
4.5 \pm 1.3 \\
5.6 \pm 1.3\end{array}$ & $\begin{array}{c}- \\
0.001 \\
0.002 \\
0.009 \\
0.001\end{array}$ \\
\hline
\end{tabular}

表中の值は, パワー值の平均值と標準誤差である $\left(\mathrm{n}=17\right.$, 平均值 \pm 標準誤差 $\left.; \mu \mathrm{V}^{2}\right)$. 検定結果には $\mathrm{p}$ 值を示す. $\mathrm{p}<0.012$ を 有意とする (Bonferroni の補正).

\section{5. 脳波デー夕}

（1）仰臥位とベッド上坐位の比較

1） $\alpha$ 带域パワー值（表 3)

ベッド上坐位では，坐位 2 期において $\mathrm{C}_{4}$ の值が仰卧 位よりも低下していた点を除くと，全ての部位で仰臥位 よりも坐位での值が増加していた，統計的な有意差は, 会話時の $\mathrm{O}_{2}$ にのみ認められた $(\mathrm{p}<0.012$, Bonferroni の補正による有意水準 $=0.05 / 4)$.

椅子坐位では, 全ての $\alpha$ パワー值が仰臥位よりも坐 位で増加していた，統計的には，坐位 2 期の $\mathrm{Fp}_{1}$ と $\mathrm{C}_{3}$, 坐位 3 期の $\mathrm{Fp}_{1}$ を除いて，有意差が認められた（ $\mathrm{p}<$ 0.012, Bonferroni の補正).

\section{2) $\beta$ 带域パワー值（表 4)}

ベッド上坐位では，坐位 2 期において $\mathrm{C}_{4}$ の值が仰卧 位よりも低下していた点を除くと，全ての部位で仰臥位 よりも坐位での值が同じか又は増加していた，統計的な 有意差は，坐位 1 期における $\mathrm{O}_{1}$ ，会話時における $\mathrm{Fp}_{1}$, $\mathrm{Fp}_{2} ， \mathrm{~F}_{4} ， \mathrm{O}_{1}$ のパワー值に認められた $(\mathrm{p}<0.012$ ， Bonfer- roni の補正).

椅子坐位では, 全ての $\beta$ パワー值が仰臥位よりも坐 位で増加していた，統計的には，坐位 2 期における $\mathrm{F}_{4}$ と $\mathrm{C}_{3}$, 坐位 3 期に扔ける $\mathrm{Fp}_{2}$ と $\mathrm{C}_{3}$ の值には認められな かったが，その他においては有意差が認められた（p< 0.012, Bonferroni の補正).

(2) ベッド上坐位と椅子坐位の比較

1） $\alpha$ 帯域パワー值（表 5)

Baseline との差のパワー值は，全ての坐位区間と測定 部位で,ベッド上坐位よりも椅子坐位の方が大きかった。

統計的には，坐位 1 期における $\mathrm{Fp}_{1}$ と $\mathrm{F}_{4}$, 坐位 2 期 に打ける $\mathrm{Fp}_{1}, \mathrm{Fp}_{2}, \mathrm{~F}_{3}, \mathrm{~F}_{4}, \mathrm{C}_{4}$ ，会話時の $\mathrm{Fp}_{1}, \mathrm{~F}_{4}, \mathrm{C}_{4}$ での有意差は認められなかったが，その他の部位では有 意に椅子坐位のパワー值が大きかった（ $\mathrm{p}<0.05 ）$.

2） $\beta$ 带域パワー值（表 6)

Baseline との差のパワー值は，全ての坐位区間と測定 部位で,ベッド上坐位よりも椅子坐位の方が大きかった. 統計的には, 坐位 1 期に扮ける $\mathrm{F}_{4}$, 坐位 2 期におけ 
表 4 坐位姿勢毎の $\beta$ 帯域脳波パワー值と多重比較の結果

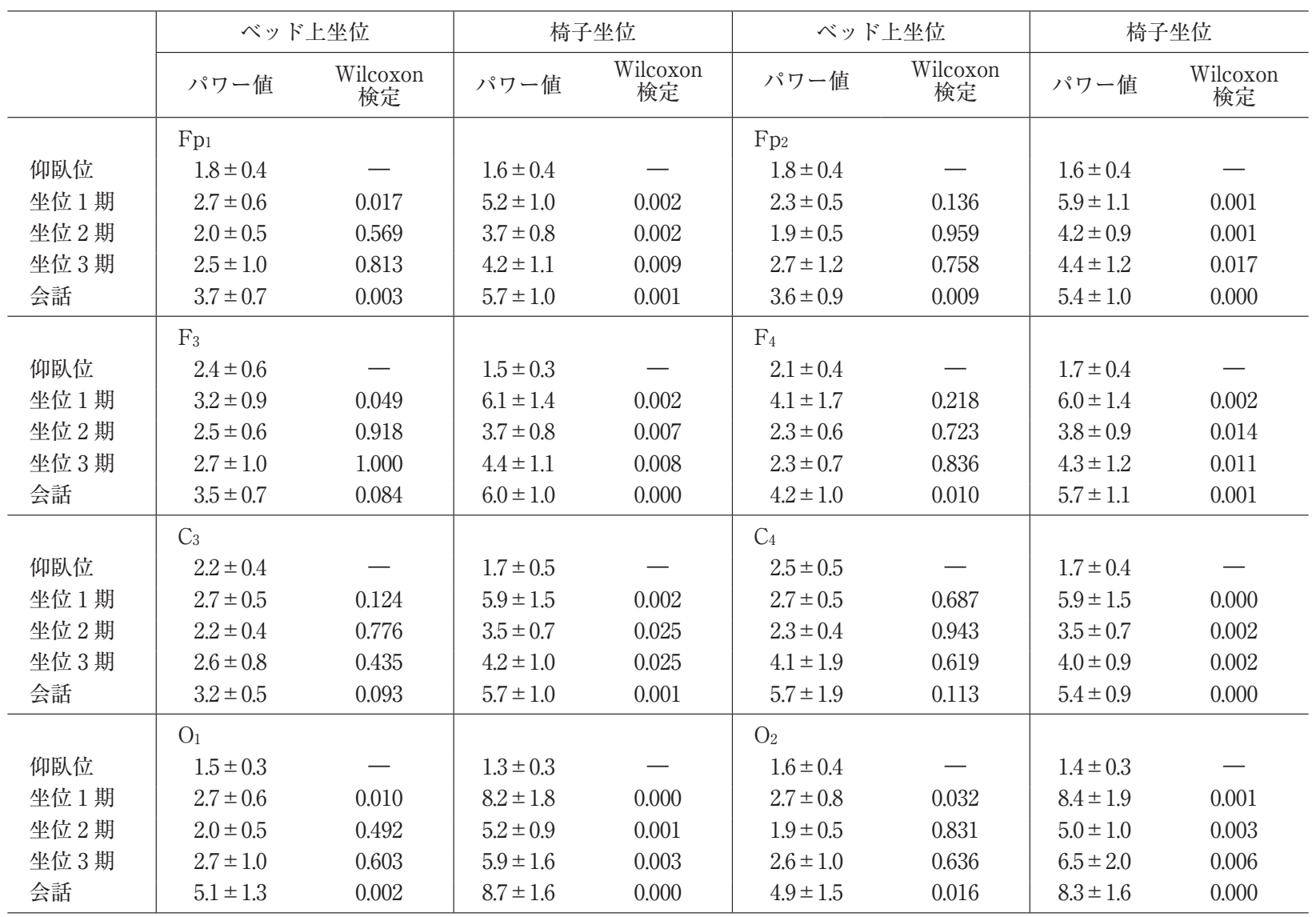

表中の值は, パワー值の平均值と標準誤差である $\left(\mathrm{n}=17\right.$, 平均值 標準誤差 $\left.; \mu \mathrm{V}^{2}\right)$. 検定結果には $\mathrm{p}$ 值を示す. $\mathrm{p}<0.012$ を有意 とする (Bonferroni の補正).

る $\mathrm{F}_{4}$ ，坐位 3 期における $\mathrm{C}_{4}$, 会話時における $\mathrm{Fp}_{2}, \mathrm{~F}_{4}$ では有意差は認められなかったが，その他の部位では有 意に椅子坐位のパワー值が大きかった $(\mathrm{p}<0.05)$.

\section{III. 考察}

1. 基礎データ

厚生労働省の平成 17 年完全生命表，また同省の平成 18 年度の介護保険の事業報告データから, 本研究の対 象者は, 全国平均よりも長寿で, 福祉施設入居者の中で は ADL はレベルが高く, 認知症レベルは平均的, 要介 護度はほぼ中央あたりの集団であると考えられた。した がって，施設に入居している高齢者の平均像に近い集団 のデータが得られたと考える.

\section{2. 測定環境}

温・湿度は，その季節におけるほぼ快適域であり，照

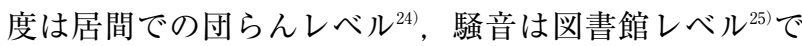
あり，収集データへの影響はないと考えられた。

3. 研究の前提条件

得られたデー夕は大きなストレスのない覚醒時のもの
であり，適切であったと考える。

4. 脳波デー夕

（1）仰臥位とベッド上坐位の比較

1） $\alpha$ 帯域パワー值

ベッド上，椅子坐位共に，仰臥位と比較して坐位でパ ワー值が増加したことより, 姿勢変化により覚醒度が高 まったことが考えられた。

多重比較の結果では, ベッド上坐位においては, 会話 時に後頭葉 $\left(\mathrm{O}_{2}\right)$ に有意差が認められたのみであり，姿 勢変化のみでは覚醒度を上げる十分な刺激にはならない ことが明らかとなった，椅子坐位では，ほとんどの坐位 区間と部位で有意差がみられたため, ベッド上坐位とは 異なり，姿勢変化そのものが覚醒度を上げる刺激となる と考えられた。

2) $\beta$ 帯域パワー值

ベッド上, 椅子坐位共に仰臥位と比較して坐位でパ ワー值が増加したことより, 姿勢変化により脳活動が高 まったと考えられた。 
表 5 ベッド上坐位と椅子坐位の $\alpha$ 帯域脳波パワー值の比較

\begin{tabular}{|c|c|c|c|c|c|c|c|}
\hline & ベッド上坐位 & 椅子坐位 & Wilcoxon 検定 & & ベッド上坐位 & 椅子坐位 & Wilcoxon 検定 \\
\hline \multicolumn{4}{|c|}{$\mathrm{Fp}_{1}$ （baseline との差） } & \multicolumn{4}{|c|}{ Fp2（baseline との差） } \\
\hline 坐位 1 期 & $0.8 \pm 0.4$ & $2.0 \pm 1.3$ & 0.287 & 坐位 1 期 & $0.7 \pm 0.4$ & $2.6 \pm 1.0$ & 0.022 \\
\hline 坐位 2 期 & $0.4 \pm 0.4$ & $1.2 \pm 0.8$ & 0.356 & 坐位 2 期 & $0.6 \pm 0.4$ & $1.9 \pm 0.7$ & 0.102 \\
\hline 坐位 3 期 & $0.5 \pm 0.6$ & $1.5 \pm 0.6$ & 0.017 & 坐位 3 期 & $0.8 \pm 0.5$ & $2.3 \pm 0.6$ & 0.011 \\
\hline 会話 & $1.8 \pm 0.9$ & $2.5 \pm 0.8$ & 0.149 & 会話 & $1.4 \pm 0.6$ & $2.9 \pm 0.7$ & 0.010 \\
\hline \multicolumn{4}{|c|}{$\mathrm{F}_{3}$ (baseline との差) } & \multicolumn{4}{|c|}{$\mathrm{F}_{4}$ (baseline との差) } \\
\hline 坐位 1 期 & $0.7 \pm 0.5$ & $3.7 \pm 1.3$ & 0.019 & 坐位 1 期 & $0.8 \pm 0.5$ & $2.7 \pm 1.0$ & 0.062 \\
\hline 坐位 2 期 & $0.5 \pm 0.4$ & $2.5 \pm 0.9$ & 0.055 & 坐位 2 期 & $0.6 \pm 0.4$ & $1.7 \pm 0.7$ & 0.309 \\
\hline 坐位 3 期 & $0.5 \pm 0.6$ & $2.5 \pm 0.8$ & 0.013 & 坐位 3 期 & $0.5 \pm 0.5$ & $2.0 \pm 0.6$ & 0.039 \\
\hline 会話 & $1.6 \pm 0.9$ & $4.0 \pm 1.0$ & 0.009 & 会話 & $1.4 \pm 0.7$ & $3.1 \pm 0.8$ & 0.055 \\
\hline \multicolumn{4}{|c|}{$\mathrm{C}_{3}$ (baseline との差) } & \multicolumn{4}{|c|}{$\mathrm{C}_{4}$ (baseline との差) } \\
\hline 坐位 1 期 & $0.6 \pm 0.4$ & $3.3 \pm 1.2$ & 0.035 & 坐位 1 期 & $0.2 \pm 0.7$ & $3.5 \pm 1.3$ & 0.011 \\
\hline 坐位 2 期 & $0.2 \pm 0.3$ & $2.0 \pm 0.9$ & 0.035 & 坐位 2 期 & $-0.1 \pm 0.6$ & $1.9 \pm 0.7$ & 0.055 \\
\hline 坐位 3 期 & $0.3 \pm 0.4$ & $2.0 \pm 0.7$ & 0.025 & 坐位 3 期 & $0.1 \pm 0.8$ & $1.8 \pm 0.6$ & 0.044 \\
\hline 会話 & $1.6 \pm 0.7$ & $3.6 \pm 0.9$ & 0.049 & 会話 & $4.1 \pm 3.2$ & $3.0 \pm 0.8$ & 0.246 \\
\hline \multicolumn{4}{|c|}{ O O $_{1}$ baseline との差) } & \multicolumn{4}{|c|}{$\mathrm{O}_{2}$ (baseline との差) } \\
\hline 坐位 1 期 & $1.0 \pm 0.4$ & $4.2 \pm 1.3$ & 0.013 & 坐位 1 期 & $0.7 \pm 0.5$ & $4.0 \pm 1.2$ & 0.009 \\
\hline 坐位 2 期 & $0.6 \pm 0.4$ & $2.7 \pm 0.8$ & 0.007 & 坐位 2 期 & $0.3 \pm 0.4$ & $2.3 \pm 0.8$ & 0.017 \\
\hline 坐位 3 期 & $1.0 \pm 0.7$ & $2.7 \pm 0.9$ & 0.015 & 坐位 3 期 & $0.8 \pm 0.6$ & $2.7 \pm 1.0$ & 0.028 \\
\hline 会話 & $1.8 \pm 0.6$ & $4.1 \pm 1.0$ & 0.015 & 会話 & $2.0 \pm 0.8$ & $3.8 \pm 0.9$ & 0.028 \\
\hline
\end{tabular}

表中の值は baseline との差の平均值と標準誤差である $\left(\mathrm{n}=17\right.$, 平均值 \pm 標準誤差 ; $\left.\mu \mathrm{V}^{2}\right)$. 検定結果には $\mathrm{p}$ 值を示す. 統計的有意 水準 : $\mathrm{p}<0.05$.

表 6 ベッド上坐位と椅子坐位の $\beta$ 帯域脳波パワー值の比較

\begin{tabular}{|c|c|c|c|c|c|c|c|}
\hline & ベッド上坐位 & 椅子坐位 & Wilcoxon 検定 & & ベッド上坐位 & 椅子坐位 & Wilcoxon 検定 \\
\hline \multicolumn{4}{|c|}{$\mathrm{Fp}_{1}$ (baseline との差) } & \multicolumn{4}{|c|}{ Fp2（baseline との差） } \\
\hline 坐位 1 期 & $0.9 \pm 0.4$ & $3.6 \pm 1.0$ & 0.044 & 坐位 1 期 & $0.5 \pm 0.4$ & $4.3 \pm 1.0$ & 0.004 \\
\hline 坐位 2 期 & $0.2 \pm 0.3$ & $2.3 \pm 0.8$ & 0.035 & 坐位 2 期 & $0.1 \pm 0.3$ & $2.6 \pm 0.7$ & 0.011 \\
\hline 坐位 3 期 & $0.7 \pm 0.9$ & $3.0 \pm 1.1$ & 0.006 & 坐位 3 期 & $1.0 \pm 1.1$ & $2.8 \pm 0.9$ & 0.049 \\
\hline 会話 & $1.9 \pm 0.4$ & $4.6 \pm 1.0$ & 0.013 & 会話 & $1.8 \pm 0.6$ & $3.8 \pm 0.8$ & 0.102 \\
\hline \multicolumn{4}{|c|}{$\mathrm{F}_{3}$ (baseline との差) } & \multicolumn{4}{|c|}{$\mathrm{F}_{4}$ (baseline との差) } \\
\hline 坐位 1 期 & $0.8 \pm 0.4$ & $4.6 \pm 1.4$ & 0.017 & 坐位 1 期 & $2.0 \pm 1.6$ & $4.3 \pm 1.4$ & 0.068 \\
\hline 坐位 2 期 & $0.1 \pm 0.3$ & $2.2 \pm 0.7$ & 0.019 & 坐位 2 期 & $0.2 \pm 0.4$ & $2.1 \pm 0.7$ & 0.065 \\
\hline 坐位 3 期 & $0.3 \pm 1.0$ & $3.0 \pm 1.0$ & 0.007 & 坐位 3 期 & $0.2 \pm 0.6$ & $2.6 \pm 0.8$ & 0.002 \\
\hline 会話 & $1.1 \pm 0.7$ & $4.6 \pm 0.9$ & 0.004 & 会話 & $2.1 \pm 0.9$ & $4.0 \pm 0.8$ & 0.076 \\
\hline \multicolumn{4}{|c|}{$\mathrm{C}_{3}$ (baseline との差) } & \multicolumn{4}{|c|}{$\mathrm{C}_{4}$ (baseline との差) } \\
\hline 坐位 1 期 & $0.5 \pm 0.4$ & $4.2 \pm 1.4$ & 0.006 & 坐位 1 期 & $0.2 \pm 0.5$ & $4.2 \pm 1.5$ & 0.004 \\
\hline 坐位 2 期 & $0.1 \pm 0.3$ & $1.8 \pm 0.8$ & 0.030 & 坐位 2 期 & $-0.2 \pm 0.4$ & $1.8 \pm 0.5$ & 0.039 \\
\hline 坐位 3 期 & $0.4 \pm 0.7$ & $2.5 \pm 1.1$ & 0.022 & 坐位 3 期 & $1.7 \pm 1.8$ & $2.3 \pm 0.7$ & 0.068 \\
\hline 会話 & $1.1 \pm 0.5$ & $4.0 \pm 1.0$ & 0.005 & 会話 & $3.2 \pm 2.1$ & $3.7 \pm 0.8$ & 0.049 \\
\hline \multicolumn{4}{|c|}{ O O $_{1}$ (baseline との差) } & \multicolumn{4}{|c|}{$\mathrm{O}_{2}$ (baseline との差) } \\
\hline 坐位 1 期 & $1.2 \pm 0.5$ & $6.9 \pm 1.8$ & 0.004 & 坐位 1 期 & $1.1 \pm 0.6$ & $7.0 \pm 1.8$ & 0.002 \\
\hline 坐位 2 期 & $0.5 \pm 0.5$ & $3.9 \pm 0.8$ & 0.004 & 坐位 2 期 & $0.3 \pm 0.5$ & $3.6 \pm 0.9$ & 0.006 \\
\hline 坐位 3 期 & $1.1 \pm 1.0$ & $4.6 \pm 1.5$ & 0.004 & 坐位 3 期 & $1.0 \pm 1.1$ & $5.0 \pm 2.0$ & 0.007 \\
\hline 会話 & $3.6 \pm 1.2$ & $7.4 \pm 1.5$ & 0.011 & 会話 & $3.3 \pm 1.5$ & $6.8 \pm 1.5$ & 0.039 \\
\hline
\end{tabular}

表中の值は baseline との差の平均值と標準誤差である $\left(\mathrm{n}=17\right.$, 平均值 \pm 標準誤差 $\left.; \mu \mathrm{V}^{2}\right)$. 検定結果には $\mathrm{p}$ 值を示す. 統計的有意水 準 : $\mathrm{p}<0.05$. 
多重比較では $\alpha$ 帯域パワーと同様に, ベッド坐位に おいては有意差が認められた坐位区間と部位が少なく， 姿勢変化のみでは脳活動の活性化のための十分な刺激に はならないことが明らかとなった。また，有意差が認め られた会話においても，ベッドにもたれたままの姿勢で は，前頭葉と後頭葉以外の部位は大きく活性化しないこ とが結果から示されたため, 脳活動を促すための姿勢と しては効果が少ないと考えられた。一方の椅子坐位では ほとんどの坐位区間と部位で有意差が認められたため, 姿勢変化そのものが脳活動を引き起こす刺激となること が示唆された。

(2) ベッド上坐位と椅子坐位の比較

1） $\alpha$ 帯域パワー值

全ての坐位区間と測定部位でベッド上坐位よりも椅子 坐位の方の值が大きく，坐位 1 期における $\mathrm{Fp}_{1}$ と $\mathrm{F}_{4}$, 坐位 2 期における $\mathrm{Fp}_{1}, \mathrm{Fp}_{2}, \mathrm{~F}_{3}, \mathrm{~F}_{4}, \mathrm{C}_{4}$ 以外では有意 差が認められたことょり, ベッド上よりも椅子坐位の方 が覚醒度が高いことが明らかになった。

2) $\beta$ 帯域パワー值

全ての坐位区間と測定部位で, ベッド上坐位よりも椅 子坐位の方の值が大きく，坐位 1 期における $\mathrm{F}_{4}$, 坐位 2 期における $\mathrm{F}_{4}$, 坐位 3 期における $\mathrm{C}_{4}$, 会話時における $\mathrm{Fp}_{2}, \mathrm{~F}_{4}$ 以外では有意差は認められたことより, ベッド 上よりも椅子坐位の方が覚醒度が高いことが明らかと なった。

\section{研究 2（健康成人, 健康高齢者, 介護福祉施設 入居者における脳波データの比較検討）}

I. 方法

1. 対象者

介護福祉施設入居高齢者 (以下, “施設高齢者”とする) と比較する対象者は, 筆者らの過去に行った研究におけ る基礎疾患のない成人（以下，“健康成人”とする $)^{19)}$ と 高齢者（以下，“健康高齢者”２00である，健康高齢者につ いては，デー夕数のバランスをとるために過去発表分 ${ }^{20}$ のものに分析を追加した.

\section{2. 脳波デー夕の比較方法}

健康成人, 健康高齢者に対して行った研究のデー夕収 集場所は大学施設内 (人工気象室 : 温度 $22^{\circ} \mathrm{C}$, 湿度 $50 \%$ ) であるが，デー夕収集方法（測定機器，手順）や分析方 法は同じである．施設高齢者を加えた三つの対象者に対 して，共通の設定であるベッド上坐位（70 度）におけ るデー夕について比較を行った。

それぞれの対象者について, baseline 值を 100 とした 場合の坐位時の值の増加率を算出し，坐位 1 期, 坐位 2
期, 坐位 3 期における各值の多重比較を行った. 多重比 較には, Bonferroniの不等式で有意水準を補正した Mann-Whitney の U 検定を用い, 有意水準は $5 \%$ とし, $\mathrm{p}<0.017(\fallingdotseq 0.05 / 3)$ を有意とした.

II. 結果

1. 対象者

健康成人の対象者は 30 人, 平均年齢は $26.67 \pm 4.69$ 歳 であった。健康高齢者の対象者は 20 人, 平均年齢は平 均年齢 $69.20 \pm 3.07$ 歳であった。施設高齢者は研究 1 を 参照.

2. 3 群における Baseline 值からの坐位時の值の増加 率の比較

（1） $\alpha$ 帯域パワー值（図 2，3，表 7，8）

$\mathrm{Fp}_{1}, \mathrm{Fp}_{2}, \mathrm{~F}_{3}, \mathrm{~F}_{4}$ の全坐位区間， $\mathrm{C}_{3}$ と $\mathrm{C}_{4}$ の坐位 2 期 と 3 期, $\mathrm{O}_{2}$ の坐位 2 期では, 3 群の中で健康高齢者にお ける baseline からの増加率が最も高かった。 $\mathrm{C}_{3}$ と $\mathrm{C}_{4}$ の 坐位 1 期と $\mathrm{O}_{2}$ の坐位 3 期では施設高齢者, また, $\mathrm{O}_{1}$ の 全坐位区間と $\mathrm{O}_{2}$ の坐位 1 期では健康成人の増加率が 3 群の中で最も高かった.

多重比較では, 全ての測定部位と坐位区間において, 健康成人と健康高齢者では有意な差は認められなかっ た. $\mathrm{Fp}_{1}, \mathrm{Fp}_{2}, \mathrm{C}_{3}$ の坐位 3 期に打いては, 健康成人の 方が施設高齢者よりも増加率が有意に高かった。また，

$\mathrm{Fp}_{1}, \mathrm{Fp}_{2}, \mathrm{~F}_{4}$ の坐位 2 期と 3 期， $\mathrm{F}_{3}, \mathrm{C}_{3}, \mathrm{C}_{4}$ の坐位 3 期 において, 健康高齢者の方が施設高齢者よりも増加率が 有意に高かった， $\mathrm{O}_{1}$ と $\mathrm{O}_{2}$ においては，どの坐位区間に おいても 3 群の間に有意な差は認められなかった.

（2） $\beta$ 帯域パワー值（図 2，3，表 9，10）

$\mathrm{Fp}_{1}$ の坐位 1 期と 2 期, $\mathrm{Fp}_{2}, \mathrm{~F}_{3}, \mathrm{~F}_{4}, \mathrm{C}_{3}, \mathrm{C}_{4}, \mathrm{O}_{1}, \mathrm{O}_{2}$ の坐位 1 期では, 3 群の中で健康成人における baseline からの増加率が最も高かった． $\mathrm{Fp}_{2}, \mathrm{~F}_{3}, \mathrm{~F}_{4}, \mathrm{C}_{3}$ の坐位 2 期と 3 期, $\mathrm{Fp}_{1}$ の坐位 1 期, $\mathrm{C}_{4}$ の坐位 2 期では健康高 齢者, また, $\mathrm{O}_{1}$ と $\mathrm{O}_{2}$ の坐位 2 期と 3 期, $\mathrm{C}_{4}$ の坐位 3 期 では施設高齢者の増加率が 3 群の中で最も高かった。

多重比較では, $\mathrm{O}_{1}$ と $\mathrm{O}_{2}$ の坐位 1 期において, 健康成 人の方が健康高齢者よりも増加率が有意に高かった。 ま た, $\mathrm{Fp}_{1}, \mathrm{Fp}_{2}, \mathrm{~F}_{3}, \mathrm{C}_{3}$ の坐位 2 期 と 3 期, $\mathrm{F}_{4}$ の坐位 2 期, $\mathrm{O}_{2}$ の坐位 1 期において, 健康成人の方が施設高齢 者よりも増加率が有意に高かった. $\mathrm{Fp}_{1}, \mathrm{Fp}_{2}$ の坐位 2 期と 3 期， $\mathrm{F}_{3} ， \mathrm{~F}_{4}$ の坐位 2 期においては, 健康高齢者の 方が施設高齢者よりも増加率が有意に高かった。 $C_{4} に$ おいては，どの坐位区間においても 3 群の間に有意な差 は認められなかった。

III. 考察 


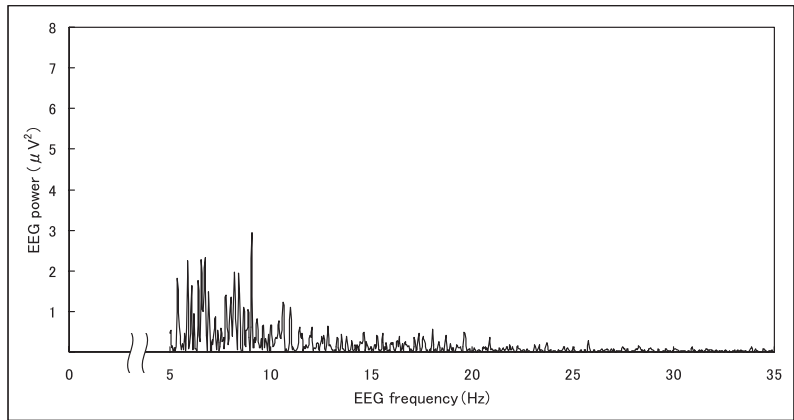

(a)健康高齢者 (65歳, 仰臥位, $\mathrm{Fp}_{1}$ )

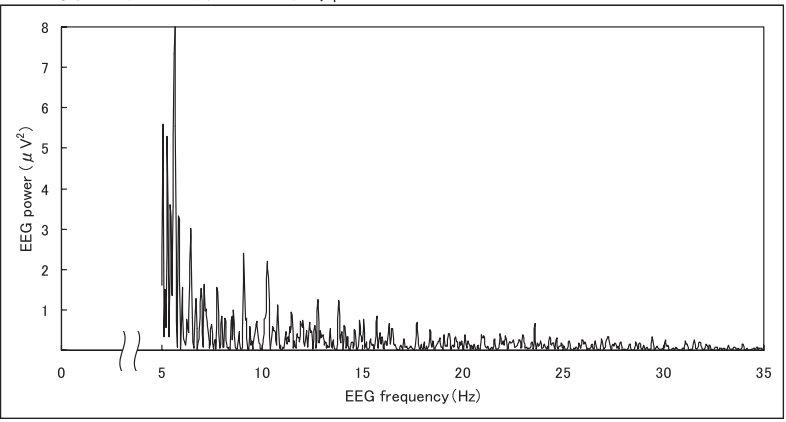

(b)健康高齢者 (65歳, 坐位 1 期, $\mathrm{Fp}_{1}$ )

図 2 健康高齢者の脳波パワースペクトルの例

\section{1. 対象者}

健康成人と健康高齢者においては共に基礎疾患がな かったため, ベッド上での仰臥位から坐位への姿勢変化 に伴う，それぞれの年齢層における正常な反応性をみる ことができたと考える。それに対し施設高龃者について は, 身の回りのケアを受けている, 認知機能に何らかの 問題のある人を含む反応が得られたと考えられる。

2. 3 群における baseline 值からの坐位時の值の増加 率の比較

(1) $\alpha$ 帯域パワー值

多重比較において，全ての測定部位と坐位区間におい て，健康成人と健康高齢者では有意な差は認められず, 施設高齢者よりも健康者 2 群の方が増加率が有意に高い 部位と坐位区間が多かったことから，健康者と身の回り のケアを受けている高齢者には，仰卧位から坐位への姿 勢変化に伴う大脳の反応性には差があることが考えられ た.

(2) $\beta$ 帯域パワー值

$\mathrm{C}_{4}$ の坐位 3 期, 後頭部 $\left(\mathrm{O}_{1}, \mathrm{O}_{2}\right)$ の坐位 2 期, 3 期以 外では, 健康者 2 群の増加率は施設高歯者よりも高く, 知的な機能を司る前頭葉 $\left(\mathrm{Fp}_{1}, \mathrm{Fp}_{2}, \mathrm{~F}_{3}, \mathrm{~F}_{4}\right)$ において は，健康者 2 群における増加率が有意に高い坐位区間が 多かったことから，認知機能を含む健康状態によって， 仰臥位から坐位への姿勢変化に伴う大脳の反応性には差
48 巻 4 号 $(2011: 7)$
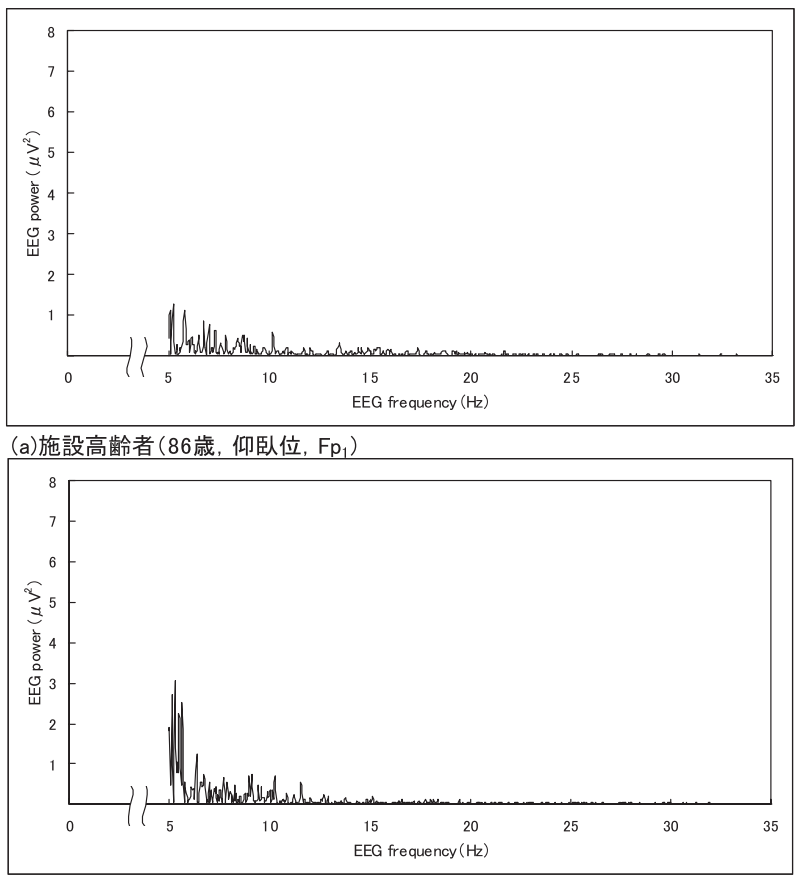

(b)施設高齢者 $\left(86\right.$ 歳, 坐位 1 期, $\mathrm{Fp}_{1}$ )

図 3 施設高齢者の脳波パワースペクトルの例

があることが考えられた。

また， $\mathrm{O}_{1}$ と $\mathrm{O}_{2}$ の坐位 1 期においては，健康成人の方 が健康高齢者, 施設高齢者よりも増加率が有意に高く, 年齢によって姿勢変化に伴う視覚情報の変化の捉え方に 差があると考えられた。

\section{研究 1 と研究 2 のまとめ}

高齢者の脳波の特徴としては, 優勢な $\alpha$ 波の周波数 減少や徐波の増加, 速波の増加, 反応性の低下等があ $ろ^{26)}$. また， $\alpha$ 波出現量と認知機能障害には負の関係が あるとの報告 ${ }^{27)}$, 知的機能の低下した高齢者では $\beta$ 波が 減少するとの報告 ${ }^{28)}, \alpha$ 帯域並びに $\beta$ 带域における定量 脳波が減少したとの報告 ${ }^{29}$ がある.

研究 1 においては, 対象者は認知機能に問題のある高 齢者であったが，仰臥位から椅子坐位への変化において は, $\alpha$ 帯域, $\beta$ 帯域共にパワー值の有意な増加がみられ, 大脳活動に及ぼす影響は大きいと考えられた。この結果 より, 大脳の活性化という観点からは, 認知機能の低下 した高齢者に対して坐位姿勢の援助を行う際にはベッド を挙上するだけではなく, 可能な限り椅子坐位の援助を 行うことが姿勢変化後 20 分の影響に関しては望ましい ことが示唆された. 但し, 姿勢変化後 20 分以降につい ては今回検討していないので言及できない.

研究 2 においては, 健康成人と健康高齢者の 2 群と, 
表 73 群におけるベッド上坐位の $\alpha$ 帯域脳波パワー 值の増加率

\begin{tabular}{|c|c|c|c|}
\hline & $\begin{array}{c}\text { 健康成人 } \\
(\mathrm{n}=30)\end{array}$ & $\begin{array}{c}\text { 健康高齢者 } \\
(\mathrm{n}=20)\end{array}$ & $\begin{array}{c}\text { 施設高齢者 } \\
(\mathrm{n}=17)\end{array}$ \\
\hline \multicolumn{4}{|c|}{$\mathrm{Fp}_{1}$ (baseline との比) } \\
\hline 坐位 1 期 & $186.9 \pm 15.7$ & $188.8 \pm 28.0$ & $155.7 \pm 22.9$ \\
\hline 坐位 2 期 & $192.0 \pm 21.3$ & $219.9 \pm 41.4$ & $136.5 \pm 27.5$ \\
\hline 坐位 3 期 & $178.9 \pm 17.0$ & $201.0 \pm 32.2$ & $165.2 \pm 60.1$ \\
\hline \multicolumn{4}{|c|}{$\mathrm{Fp}_{2}$ (baseline との比) } \\
\hline 坐位 1 期 & $181.7 \pm 14.7$ & $191.9 \pm 39.6$ & $144.2 \pm 22.9$ \\
\hline 坐位 2 期 & $179.0 \pm 19.1$ & $203.5 \pm 30.9$ & $134.6 \pm 28.9$ \\
\hline 坐位 3 期 & $168.6 \pm 13.6$ & $207.2 \pm 35.6$ & $171.4 \pm 57.4$ \\
\hline \multicolumn{4}{|c|}{$\mathrm{F}_{3}$ (baseline との比) } \\
\hline 坐位 1 期 & $141.1 \pm 10.3$ & $157.2 \pm 33.3$ & $142.9 \pm 23.0$ \\
\hline 坐位 2 期 & $173.3 \pm 21.3$ & $192.9 \pm 49.3$ & $130.3 \pm 23.8$ \\
\hline 坐位 3 期 & $162.9 \pm 16.2$ & $185.1 \pm 32.6$ & $129.3 \pm 33.0$ \\
\hline \multicolumn{4}{|c|}{$\mathrm{F}_{4}$ (baseline との比) } \\
\hline 坐位 1 期 & $158.6 \pm 19.1$ & $160.2 \pm 32.4$ & $140.4 \pm 26.7$ \\
\hline 坐位 2 期 & $160.1 \pm 20.7$ & $197.9 \pm 39.0$ & $126.5 \pm 24.8$ \\
\hline 坐位 3 期 & $152.8 \pm 13.7$ & $196.0 \pm 38.4$ & $114.7 \pm 21.7$ \\
\hline \multicolumn{4}{|c|}{$\mathrm{C}_{3}$ (baseline との比) } \\
\hline 坐位 1 期 & $129.5 \pm 10.4$ & $125.0 \pm 14.1$ & $142.9 \pm 26.2$ \\
\hline 坐位 2 期 & $146.6 \pm 16.1$ & $157.1 \pm 24.1$ & $123.4 \pm 22.5$ \\
\hline 坐位 3 期 & $149.2 \pm 13.0$ & $152.8 \pm 21.0$ & $127.5 \pm 34.5$ \\
\hline \multicolumn{4}{|c|}{$\mathrm{C}_{4}$ (baseline との比) } \\
\hline 坐位 1 期 & $127.2 \pm 13.3$ & $123.7 \pm 14.8$ & $135.0 \pm 25.5$ \\
\hline 坐位 2 期 & $152.9 \pm 19.5$ & $165.5 \pm 24.6$ & $118.8 \pm 24.0$ \\
\hline 坐位 3 期 & $146.6 \pm 15.2$ & $161.7 \pm 25.9$ & $130.1 \pm 40.7$ \\
\hline \multicolumn{4}{|c|}{ O1 (baseline との比) } \\
\hline 坐位 1 期 & $184.3 \pm 20.8$ & $121.1 \pm 13.3$ & $173.2 \pm 33.2$ \\
\hline 坐位 2 期 & $170.8 \pm 21.4$ & $162.4 \pm 36.0$ & $144.1 \pm 34.0$ \\
\hline 坐位 3 期 & $187.5 \pm 21.7$ & $168.7 \pm 34.1$ & $180.8 \pm 62.8$ \\
\hline \multicolumn{4}{|c|}{$\mathrm{O}_{2}$ (baseline との比) } \\
\hline 坐位 1 期 & $189.6 \pm 22.5$ & $131.1 \pm 16.9$ & $160.4 \pm 33.5$ \\
\hline 坐位 2 期 & $173.7 \pm 19.8$ & $180.2 \pm 35.2$ & $146.8 \pm 38.2$ \\
\hline 坐位 3 期 & $166.0 \pm 16.7$ & $165.0 \pm 26.5$ & $196.1 \pm 80.1$ \\
\hline
\end{tabular}

表中の值は baseline を 100 とした場合の比（\%).

施設高齢者の間には，仰卧位から坐位への姿勢変化に伴 う大脳の反応性には差があることが示唆された。この結 果より, 認知機能が低下している高齢者では, 先行研究 における $\alpha, \beta$ 带域の脳波の低下という結果に加え, 刺 激に対する baseline からの脳波の増加率の低下がみら れる可能性が示された．本研究においてはデー夕数が少 ないため, 今後デー夕数を増やして検討を行っていく必 要がある.

\section{結 語}

仰臥位から坐位への姿勢変化がもたらす大脳活性は, 姿勢変化後 20 分間に関してはベッド上坐位よりも椅子
表 83 群におけるベッド上坐位の $\alpha$ 帯域脳波パワー 值の多重比較

\begin{tabular}{|c|c|c|c|}
\hline & $\begin{array}{l}\text { 健康成人と } \\
\text { 健康高齢者 }\end{array}$ & $\begin{array}{l}\text { 健康成人と } \\
\text { 施設高齢者 }\end{array}$ & $\begin{array}{c}\text { 健康高齢者と } \\
\text { 施設高齢者 }\end{array}$ \\
\hline $\begin{array}{l}\mathrm{Fp}_{1} \\
\text { 坐位 } 1 \text { 期 } \\
\text { 坐位 } 2 \text { 期 } \\
\text { 坐位 } 3 \text { 期 }\end{array}$ & $\begin{array}{l}0.539 \\
0.607 \\
0.890\end{array}$ & $\begin{array}{l}0.086 \\
0.018 \\
0.007\end{array}$ & $\begin{array}{l}0.257 \\
0.004 \\
0.004\end{array}$ \\
\hline $\begin{array}{l}\mathrm{Fp}_{2} \\
\text { 坐位 } 1 \text { 期 } \\
\text { 坐位 } 2 \text { 期 } \\
\text { 坐位 } 3 \text { 期 }\end{array}$ & $\begin{array}{l}0.458 \\
0.488 \\
0.782\end{array}$ & $\begin{array}{l}0.063 \\
0.028 \\
0.016\end{array}$ & $\begin{array}{l}0.244 \\
0.007 \\
0.011\end{array}$ \\
\hline $\begin{array}{l}\mathrm{F}_{3} \\
\quad \text { 坐位 } 1 \text { 期 } \\
\text { 坐位 } 2 \text { 期 } \\
\text { 坐位 } 3 \text { 期 }\end{array}$ & $\begin{array}{l}0.285 \\
0.905 \\
0.968\end{array}$ & $\begin{array}{l}0.611 \\
0.054 \\
0.025\end{array}$ & $\begin{array}{l}0.821 \\
0.060 \\
0.015\end{array}$ \\
\hline $\begin{array}{l}\mathrm{F}_{4} \\
\text { 坐位 } 1 \text { 期 } \\
\text { 坐位 } 2 \text { 期 } \\
\text { 坐位 } 3 \text { 期 }\end{array}$ & $\begin{array}{l}0.362 \\
0.191 \\
0.649\end{array}$ & $\begin{array}{l}0.241 \\
0.097 \\
0.035 \\
\end{array}$ & $\begin{array}{l}0.537 \\
0.015 \\
0.013\end{array}$ \\
\hline $\begin{array}{l}\mathrm{C}_{3} \\
\text { 坐位 } 1 \text { 期 } \\
\text { 坐位 } 2 \text { 期 } \\
\text { 坐位 } 3 \text { 期 }\end{array}$ & $\begin{array}{l}0.593 \\
0.766 \\
0.843\end{array}$ & $\begin{array}{l}1.000 \\
0.069 \\
0.007\end{array}$ & $\begin{array}{l}0.662 \\
0.060 \\
0.013\end{array}$ \\
\hline $\begin{array}{l}\mathrm{C}_{4} \\
\text { 坐位 } 1 \text { 期 } \\
\text { 坐位 } 2 \text { 期 } \\
\text { 坐位 } 3 \text { 期 }\end{array}$ & $\begin{array}{l}0.905 \\
0.593 \\
0.736\end{array}$ & $\begin{array}{l}0.690 \\
0.106 \\
0.034\end{array}$ & $\begin{array}{l}0.916 \\
0.033 \\
0.010\end{array}$ \\
\hline $\begin{array}{l}\mathrm{O}_{1} \\
\text { 坐位 } 1 \text { 期 } \\
\text { 坐位 } 2 \text { 期 } \\
\text { 坐位 } 3 \text { 期 }\end{array}$ & $\begin{array}{l}0.060 \\
0.843 \\
0.452\end{array}$ & $\begin{array}{l}0.535 \\
0.156 \\
0.066\end{array}$ & $\begin{array}{l}0.357 \\
0.167 \\
0.141\end{array}$ \\
\hline $\begin{array}{l}\mathrm{O}_{2} \\
\text { 坐位 } 1 \text { 期 } \\
\text { 坐位 } 2 \text { 期 } \\
\text { 坐位 } 3 \text { 期 }\end{array}$ & $\begin{array}{l}0.113 \\
0.905 \\
0.539\end{array}$ & $\begin{array}{l}0.223 \\
0.060 \\
0.054\end{array}$ & $\begin{array}{l}0.988 \\
0.080 \\
0.080\end{array}$ \\
\hline
\end{tabular}

表中の値は Mann-Whitney 検定結果の $\mathrm{p}$ 値.

$\mathrm{p}<0.017(\doteqdot 0.05 / 3)$ を有意とする

坐位の方が大きいことが示された

椅子や車椅子で坐位姿勢をとることができれば，活動 範囲が屋外に広がる可能性がある，外出の制限は QOL を低くする ${ }^{30)}$ との報告がある，QOLを維持，向上させ るという点からも, 坐位姿勢の援助は重要であると考え られる。

本研究においては，対象者が施設入居者であるため, 坐位姿勢の援助を常に受けている人であった．坐位姿勢 の援助を受ける機会が少なく, 臥床時間の長い人でどう であるかは，今後の検討課題である。 また，今回は姿勢 変化に伴う脳活動についての検証であるため, ケア実施 時に抒ける姿勢と脳活動については，今後検討を行う必 
表 93 群におけるベッド上坐位の $\beta$ 帯域脳波パワー 值の増加率

\begin{tabular}{|c|c|c|c|}
\hline & $\begin{array}{c}\text { 健康成人 } \\
(\mathrm{n}=30)\end{array}$ & $\begin{array}{c}\text { 健康高齢者 } \\
(\mathrm{n}=20)\end{array}$ & $\begin{array}{c}\text { 施設高齢者 } \\
\quad(\mathrm{n}=17)\end{array}$ \\
\hline \multicolumn{4}{|c|}{$\mathrm{Fp}_{1}$ (baseline との比) } \\
\hline 坐位 1 期 & $212.0 \pm 20.7$ & $201.3 \pm 38.8$ & $195.5 \pm 40.3$ \\
\hline 坐位 2 期 & $211.0 \pm 26.2$ & $133.0 \pm 22.1$ & $133.0 \pm 22.1$ \\
\hline 坐位 3 期 & $191.1 \pm 23.3$ & $247.2 \pm 49.1$ & $147.3 \pm 44.2$ \\
\hline \multicolumn{4}{|c|}{$\mathrm{Fp}_{2}$ (baseline との比) } \\
\hline 坐位 1 期 & $222.6 \pm 20.6$ & $188.1 \pm 29.9$ & $153.5 \pm 18.6$ \\
\hline 坐位 2 期 & $229.2 \pm 33.1$ & $239.5 \pm 33.2$ & $111.2 \pm 13.9$ \\
\hline 坐位 3 期 & $235.0 \pm 51.4$ & $258.9 \pm 54.1$ & $147.3 \pm 42.0$ \\
\hline \multicolumn{4}{|c|}{$\mathrm{F}_{3}$ (baseline との比) } \\
\hline 坐位 1 期 & $188.1 \pm 14.7$ & $164.1 \pm 24.4$ & $169.7 \pm 26.9$ \\
\hline 坐位 2 期 & $161.3 \pm 10.7$ & $186.5 \pm 20.2$ & $127.9 \pm 23.2$ \\
\hline 坐位 3 期 & $168.1 \pm 14.8$ & $201.3 \pm 34.8$ & $135.1 \pm 39.7$ \\
\hline \multicolumn{4}{|c|}{$\mathrm{F}_{4}$ (baseline との比) } \\
\hline 坐位 1 期 & $211.1 \pm 28.2$ & $171.1 \pm 23.2$ & $209.8 \pm 57.3$ \\
\hline 坐位 2 期 & $158.3 \pm 11.1$ & $178.7 \pm 14.9$ & $132.4 \pm 31.6$ \\
\hline 坐位 3 期 & $156.6 \pm 15.7$ & $195.6 \pm 28.5$ & $119.4 \pm 18.9$ \\
\hline \multicolumn{4}{|c|}{$\mathrm{C}_{3}$ (baseline との比) } \\
\hline 坐位 1 期 & $185.4 \pm 15.7$ & $143.9 \pm 15.4$ & $174.2 \pm 36.3$ \\
\hline 坐位 2 期 & $148.0 \pm 9.4$ & $152.5 \pm 14.3$ & $142.4 \pm 35.4$ \\
\hline 坐位 3 期 & $138.0 \pm 9.3$ & $182.9 \pm 43.6$ & $151.8 \pm 52.9$ \\
\hline \multicolumn{4}{|c|}{$\mathrm{C}_{4}$ (baseline との比) } \\
\hline 坐位 1 期 & $170.4 \pm 13.7$ & $153.0 \pm 15.6$ & $144.4 \pm 24.5$ \\
\hline 坐位 2 期 & $140.2 \pm 7.4$ & $153.8 \pm 11.3$ & $121.3 \pm 22.6$ \\
\hline 坐位 3 期 & $132.6 \pm 9.8$ & $164.6 \pm 24.1$ & $188.4 \pm 63.2$ \\
\hline \multicolumn{4}{|c|}{ O1 (baseline との比) } \\
\hline 坐位 1 期 & $275.4 \pm 48.1$ & $139.0 \pm 10.4$ & $261.7 \pm 62.9$ \\
\hline 坐位 2 期 & $142.6 \pm 7.5$ & $136.8 \pm 8.9$ & $172.1 \pm 46.0$ \\
\hline 坐位 3 期 & $134.6 \pm 8.2$ & $124.7 \pm 10.5$ & $253.2 \pm 116.0$ \\
\hline \multicolumn{4}{|c|}{$\mathrm{O}_{2}$ (baseline との比) } \\
\hline 坐位 1 期 & $298.3 \pm 54.9$ & $156.8 \pm 18.1$ & $235.6 \pm 76.9$ \\
\hline 坐位 2 期 & $147.3 \pm 11.9$ & $150.5 \pm 12.1$ & $183.6 \pm 73.4$ \\
\hline 坐位 3 期 & $144.1 \pm 14.6$ & $139.8 \pm 13.4$ & $308.0 \pm 177.7$ \\
\hline
\end{tabular}

表中の值は baselineを 100 とした場合の比（\%).

要があると考える，さらには，他の脳波帯域のパワー值 の検討, 認知症の程度や型毎による比較等の検討も行っ ていく必要がある.

謝辞: 本研究は, 日本学術振興会科学研究費補助金基 盤研究 C（課題番号 19592440）で行ったものの一部で ある。また，フランスベッドメディカルホームケア研究 助成財団の第 17 回研究助成事業助成で行った研究デー 夕にも分析を加えさせて頂いた．最後に，本研究を行う にあたりご協力いただいた，(福）京都福祉サービス協会 の介護老人福祉施設の入居者, ご家族，スタッフの皆様 に深謝致します。
表 103 群におけるベッド上坐位の $\beta$ 帯域脳波パワー 值の多重比較

\begin{tabular}{|c|c|c|c|}
\hline & $\begin{array}{l}\text { 健康成人と } \\
\text { 健康高齢者 }\end{array}$ & $\begin{array}{l}\text { 健康成人と } \\
\text { 施設高齢者 }\end{array}$ & $\begin{array}{c}\text { 健康高齢者と } \\
\text { 施設高齢者 }\end{array}$ \\
\hline $\begin{array}{l}\mathrm{Fp}_{1} \\
\text { 坐位 } 1 \text { 期 } \\
\text { 坐位 } 2 \text { 期 } \\
\text { 坐位 } 3 \text { 期 }\end{array}$ & $\begin{array}{l}0.251 \\
0.227 \\
0.342\end{array}$ & $\begin{array}{l}0.215 \\
0.008 \\
0.014\end{array}$ & $\begin{array}{l}0.988 \\
0.000 \\
0.010\end{array}$ \\
\hline $\begin{array}{l}\mathrm{Fp}_{2} \\
\text { 坐位 } 1 \text { 期 } \\
\text { 坐位 } 2 \text { 期 } \\
\text { 坐位 } 3 \text { 期 }\end{array}$ & $\begin{array}{l}0.143 \\
0.607 \\
0.621 \\
\end{array}$ & $\begin{array}{l}0.044 \\
0.000 \\
0.008 \\
\end{array}$ & $\begin{array}{l}0.684 \\
0.000 \\
0.006 \\
\end{array}$ \\
\hline $\begin{array}{l}\mathrm{F}_{3} \\
\text { 坐位 } 1 \text { 期 } \\
\text { 坐位 } 2 \text { 期 } \\
\text { 坐位 } 3 \text { 期 }\end{array}$ & $\begin{array}{l}0.021 \\
0.476 \\
0.722\end{array}$ & $\begin{array}{l}0.177 \\
0.010 \\
0.006\end{array}$ & $\begin{array}{l}0.775 \\
0.007 \\
0.039\end{array}$ \\
\hline $\begin{array}{l}\mathrm{F}_{4} \\
\text { 坐位 } 1 \text { 期 } \\
\text { 坐位 } 2 \text { 期 } \\
\text { 坐位 } 3 \text { 期 }\end{array}$ & $\begin{array}{l}0.118 \\
0.276 \\
0.322 \\
\end{array}$ & $\begin{array}{l}0.077 \\
0.012 \\
0.101 \\
\end{array}$ & $\begin{array}{l}0.517 \\
0.005 \\
0.036 \\
\end{array}$ \\
\hline $\begin{array}{l}\mathrm{C}_{3} \\
\text { 坐位 } 1 \text { 期 } \\
\text { 坐位 } 2 \text { 期 } \\
\text { 坐位 } 3 \text { 期 }\end{array}$ & $\begin{array}{l}0.017 \\
0.859 \\
0.384\end{array}$ & $\begin{array}{l}0.066 \\
0.012 \\
0.016\end{array}$ & $\begin{array}{l}0.821 \\
0.052 \\
0.097\end{array}$ \\
\hline $\begin{array}{l}\mathrm{C}_{4} \\
\text { 坐位 } 1 \text { 期 } \\
\text { 坐位 } 2 \text { 期 } \\
\text { 坐位 } 3 \text { 期 }\end{array}$ & $\begin{array}{l}0.212 \\
0.513 \\
0.452\end{array}$ & $\begin{array}{l}0.135 \\
0.057 \\
0.215\end{array}$ & $\begin{array}{l}0.311 \\
0.056 \\
0.149\end{array}$ \\
\hline $\begin{array}{l}\mathrm{O}_{1} \\
\text { 坐位 } 1 \text { 期 } \\
\text { 坐位 } 2 \text { 期 } \\
\text { 坐位 } 3 \text { 期 }\end{array}$ & $\begin{array}{l}0.000 \\
0.607 \\
0.322\end{array}$ & $\begin{array}{l}0.188 \\
0.535 \\
0.121\end{array}$ & $\begin{array}{l}0.097 \\
0.641 \\
0.407\end{array}$ \\
\hline $\begin{array}{l}\mathrm{O}_{2} \\
\text { 坐位 } 1 \text { 期 } \\
\text { 坐位 } 2 \text { 期 } \\
\text { 坐位 } 3 \text { 期 }\end{array}$ & $\begin{array}{l}0.000 \\
0.621 \\
0.820\end{array}$ & $\begin{array}{l}0.004 \\
0.092 \\
0.106\end{array}$ & $\begin{array}{l}0.940 \\
0.085 \\
0.244\end{array}$ \\
\hline
\end{tabular}

表中の值は Mann-Whitney 検定結果の $\mathrm{p}$ 值. $\mathrm{p}<0.017 （ \doteqdot 0.05 / 3 ）$ を有意とする.

\section{文献}

1）見藤隆子ほか編：看護学事典, 日本看護協会出版会, 東 京, 2003 .

2) Donaldson LJ, Clayton DG, Clarke M: The elderly in residential care: Mortality in relation to functional capacity. J Epidemiol Community Health 1980; 34: 96-101.

3) Warren MD, Knight R: Mortality in relation to the functional capacities of people with disabilities living at home. J Epidemiol Community Health 1982; 36: 220-223.

4) Donaldson LJ, Jagger C: Survival and functional capacity: Three year follow up of an elderly population in hospitals and homes. J Epidemiol Community Health 1983; 37: 176-179.

5) Reuben DB, Rubenstein LV, Hirsch SH, Hays RD: Value 
of functional state as a Predictor of Mortality: Results of a prospective study. Am J Med 1992; 93: 663-669.

6）川崎一幸：安楽な座位から快適な生活の広がり：車椅子 個人購入から QOL 向上を求めた 1 年間の取り組み. 理 療 2005; 34 (4): 57-58.

7) 根本伸仁, 川島 勉, 大川原真澄, 中山敏光, 福地育美, 中川千恵子ほか：QOL 向上を目指して：まずは坐位保 持から. 善仁会研報 2007;28:74-76.

8) Moruzzi G, Magoun HW: Brain stem reticular formation and activation of the EEG. 1949. J Neuropsychiatry Clin Neurosci 1995; 7 (2): 251-267.

9）川島みどり, 菱沼典子編：看護技術の科学と検証：日常 ケアの根拠を明らかにする．ナーシング・トゥデイ別冊 9 号, 1996, p50-56.

10）大久保暢子, 雨宮聡子, 菱沼典子：背面開放端座位ヶア の導入により意識レベルが改善した事例 遷延性意識障 害患者 1 事例の入院中から在宅での経過を追って。聖路 加看会誌 2001;5 (1):58-63.

11）川島みどり：こんな助っ人欲しいな！背面開放型端座位 保持具を考案. 看学誌 1993; 57 (9):818-821.

12）菱沼典子，能條多恵子，平松則子，大久保暢子：技術の 科学的検証：背面開放座位（座ろうくん）．日看技学誌 2003; 2 (1): 55-57.

13) Lowry CA: Functional subsets of serotonergic neurons, Implications for control of the hypothalamic-pituitaryadrenal axis. J Neuroendocrinol 2002; 14: 911-923.

14) Yokoi Y, Aoki K: Relationship between blood pressure and heart-rate variability during graded head-up tilt. Acta Physiol Scand 1999; 165: 155-161.

15）大久保暢子，向後裕子，水沢亮子，菱沼典子：座位によ る背面開放が自律神経活動に及ぼす影響：両足底を床面 に接地しての背面密着型座位との比較. 日看会誌 2002 ; 11 (1): 40-46.

16）黑木祐子, 長坂 猛, 安部浩太郎, 須永 清, 小林敏生, 榊原吉一ほか：健康高齢者おける自力坐位保持ならびに 背面密着坐位中の循環動態及び自律神経活性. 日看研会 誌 2004; 127 (2): 93-100.

17) Papakostas GI, Petersen T, Mischoulon D, Hughes ME, Alpert JE, Nierenberg AA, et al:: Serum cholesterol and serotonergic function in major depressive disorder. Psy- chiatry Res 2003; 118: 137-145.

18）阿曾洋子, 高鳥毛敏雄, 山本恵子, 多田羅浩三 : 在宅寝 たきり老人の自立意欲と生命予後. 厚生の指標 $1995 ; 42$ (6): 17-23.

19）徳重あつ子, 阿曽洋子, 伊部亜希, 岡みゆき, 片山 恵 : 脳波計測に基づく仰臥位から坐位への姿勢変化がもたら す脳活性についての研究. 生体医工学 2009; 47 (1): 1527.

20）徳重あつ子, 阿曽洋子, 伊部亜希, 岡みゆき, 片山 恵, 宮嶋正子ほか：健康高齢者における大脳と自律神経活動 からみた座位姿勢の有効性の検証 : 機能低下予防のため の看護ケアアプローチとして．フランスベッドメディカ ルホームケア研究助成財団第 17 回研究助成事業助成報 告書, 2007, p161-201.

21) Bear MF, Connors BW, Paradiso MA: Neuroscience: Exploring the brain, 2nd ed, Lippincott Williams \& Wilkins, Philadelphia, 2001, p606-636.

22）藤木建夫：覚醒時における脳の活動水準の日内変動に関 する脳波学的研究. 日医大誌 1983; 50 (1):29-41.

23) 岡本 基 : 成人の正常脳波. 最新臨床脳波学(佐藤光源, 松岡洋夫編)，普及版，朝倉書店，東京， 2006, p85-108.

24）氏家幸子，阿曽洋子，井上智子：基礎看護技術 I，第 6 版, 医学書院, 東京, 2005, p193-259.

25）末岡真一：都市部における騒音の目安について．東京環 境科研年報, 2005, p209-214.

26）大熊輝雄：臨床脳波学, 医学書院, 東京, 1999, p115-119.

27）松浦雅人, 小島卓也, 浅川 理, 小山恵子, 平沢秀人 : 加齢に伴う脳波の変化. 臨脳波 1995; 37 (3): 143-148.

28) Williamson PC, Merskey H, Morrison S, Rabheru K, Fox $\mathrm{H}$, Wands K, et al.: Quantitative electroencephalographic correlates of cognitive decline in normal elderly subjects. Arch Neurol 1990; 47: 1185-1188.

29）朝日晴彦, 中野隆史, 駒橋 徹, 宮坂松衛 : 老年期痴呆 における定量解析脳波と局所脳血流の相関について：ア ルツハイマー型痴呆と脳血管性痴呆の比較. 臨脳波 1993; 35 (3): 169-175.

30）森下路子, 川崎涼子, 中尾理恵子, 半澤節子：後期高齢 女性の QOL と居住歴 ·生活 - 健康状態との関連. 保健 学研 2007; 19 (2): 31-41. 


\title{
Electroencephalographic examination of the cerebral activity of elderly people living in a nursing home after postural change from supine to sitting positions
}

\author{
Atsuko Tokushige ${ }^{1)}$, Yoko Aso ${ }^{2)}$, Aki Ibe ${ }^{2)}$, Megumi Katayama ${ }^{3)}$ and Shizuka Kimura ${ }^{4)}$
}

\section{Abstract}

Aim: We investigated the cerebral activity of elderly persons living in a nursing home in the sitting position by analyzing the electroencephalography findings of postural changes in the supine and sitting positions.

Methods: This study was approved by the Health Ethics Committee of Osaka University. The subjects were 17 elderly people ( 4 men and 13 women, average age $85.35 \pm 8.26$ years) living in a nursing home. Electroencephalograms were obtained in 8 cerebral regions (the left front-polar $\left(\mathrm{Fp}_{1}\right)$; right front-polar $\left(\mathrm{Fp}_{2}\right)$; left frontal $\left(\mathrm{F}_{3}\right)$; right frontal $\left(\mathrm{F}_{4}\right)$; left central $\left(\mathrm{C}_{3}\right)$; right central $\left(\mathrm{C}_{4}\right)$; left occipital $\left(\mathrm{O}_{1}\right)$ and right occipital $\left.\left(\mathrm{O}_{2}\right)\right)$ while subjects sat in a head-up position in bed, or in a chair or wheelchair. Measurement was obtained over 5-minute supine, 15-minute sitting, and 5-minute conversation periods. We performed the fast Fourier transform on measured electroencephalograms to calculate the average power values of alpha band components $(8-13 \mathrm{~Hz})$ and beta band components $(13-30 \mathrm{~Hz})$ for each cerebral section.

Results: Compared with the supine position, the sitting position in bed did not show a significant increase in power values, whereas the sitting position in a chair showed significant increases in power values in all regions. Most of the time, the findings of patients sitting position in a chair showed significantly higher power values than those of patients sitting in bed in all regions.

Conclusions: During the 20 minutes after postural change from the supine to sitting positions, the cerebral activity of subjects sitting in a chair was higher than that of subjects sitting in bed.

Key words: Electroencephalogram (EEG), Sitting position, Nursing home, Elderly people, Cerebral activity

(Nippon Ronen Igakkai Zasshi 2011; 48: 378-390)

1) School of Nursing Science, Meiji University of Integrative Medicine

2) Division of Health Science, Osaka University Graduate School of Medicine

3) Kobe University Graduate School of Health Science

4) School of Nursing Science, Takarazuka University 